\title{
Pengaruh Kualitas Audit, Debt Default (Kegagalan Hutang) dan Ukuran Perusahaan terhadap Penerimaan Opini Audit Going Concern pada Subsektor Perusahaan Tekstil \& Garment Yang Terdaftar Di Bursa Efek Indonesia Pada Periode 2014-2017
}

\author{
Irene Chandra \\ Universitas Prima Indonesia \\ irenechandraaa@gmail.com
}

Fansra Septiman Zai

Universitas Prima Indonesia

Fansrazaii@gmail.com

\author{
Steven Cianata \\ Universitas Prima Indonesia \\ stevencianata@gmail.com
}

Alvina

Universitas Prima Indonesia vinasultann@gmail.com

\author{
Namira Ufrida Rahmi \\ Universitas Prima Indonesia \\ namie2883@gmail.com
}

Maisara Batubara

Universitas Prima Indonesia

sharabatubara@gmail.com

\begin{abstract}
ABSTRAK
Going concern audit opinion is an audit opinion with an explanatory paragraph regarding to an auditor consideration that has an inability or significant uncertainty on operating a company life sustainability in the future time. There are many factors that affect going concern audit opinion which are Audit Quality, Debt Default, and Firm Size. The purpose of this research is to examine and to analyze the affect of Audit Quality, Debt Default, and Firm Size toward Revenues Going Concern Audit Opinion on the company subsector of textile and garment listed on the Indonesia Stock Exchange in 2014-2017. The types of the data collections is descriptive statistics with a quantitative approach. The Method of collective data used documentation study and logistic regression analysis. Using the population based on the financial statement of textile and garment companies that is listed on Indonesia Stock Exchange in 2014-2017. The technique which used for sampling is purposive sampling method. The result of this study showed that Audit Quality, Debt Default and Firm Size have simultant effect of Revenues Going Concern Audit Opinion with a significant value $0.010<0.05$. Audit Quality and Firm Size did not effect Revenues Going Concern Audit Opinion partialy. Debt Default effect the Revenues Going Concern Audit Opinion.
\end{abstract}

Keywords : Audit Quality, Debt Default, Firm Size, Going Concern Audit Opinion

ABSTRAK

Opini audit going concern merupakan opini audit dengan paragraf penjelasan mengenai pertimbangan auditor bahwa terdapat ketidakmampuan atau 
ketidakpastian signifikan atas kelangsungan hidup perusahaan dalam menjalankan operasinya pada masa mendatang. Banyak faktor yang mempengaruhi opini audit going concern diantaranya Kualitas Audit, Debt Default dan Ukuran Perusahaan. Tujuan penelitian ini adalah untuk menguji dan menganalisis pengaruh Kualitas Audit, Debt Default dan Ukuran Perusahaan terhadap Penerimaan Opini Audit Going Concern pada Subsektor Perusahaan Tekstil dan Garmen yang terdaftar di BEI periode 2014-2017. Jenis penelitian yang digunakan adalah statistik deskriptif dengan pendekatan kuantitatif. Metode pengumpulan data adalah metode studi dokumentasi dengan metode analisis regresi logistik. Populasi yang digunakan adalah laporan keuangan perusahaan Tekstil dan Garmen yang terdaftar di BEI periode 2014-2017. Teknik pengambilan sampel menggunakan metode purposive sampling. Hasil penelitian menunjukkan secara simultan Kualitas Audit, Debt Default dan Ukuran Perusahaan berpengaruh terhadap Penerimaan Opini Audit Going Concern dimana diperoleh nilai signikan $0.010<0.05$. Secara parsial Kualitas Audit dan Ukuran Perusahaan tidak berpengaruh terhadap Penerimaan Opini Audit Going Concern. Debt Default berpengaruh terhadap Penerimaan Opini Audit Going Concern.

Kata kunci : Kualitas Audit, Debt Deault, Ukuran Perusahaan, Opini Audit Going Concern

\section{Pendahuluan}

Industri tekstil dan garment di Indonesia merupakan salah satu tulang punggung industri manufaktur dan juga industri prioritas nasional yang masih prospektif untuk dikembangkan. Selain itu industri tekstil dan garment memberikan kontribusi cukup besar terhadap pertumbuhan ekonomi serta menciptakan lapangan kerja yang cukup besar, dan industri ini juga mendorong peningkatan investasi di dalam dan diluar negeri.

Dalam mempertahankan kelangsungan hidup (going concern) usaha dapat dilakukan dengan mengasumsikan going concern. Maka dari itu yang menjadi salah satu pertimbangan para investor dalam pengambilan keputusan berinvestasi adalah opini audit atas laporan keuangannya. Oleh karena itu, auditor sangat diandalkan dalam memberikan informasi bagi para investor. Going concern adalah kelangsungan hidup suatu badan usaha. (Standart Akuntansi Keuangan , 2009) dalam Syafriliani (2015). Going concern juga merupakan asumsi dasar dalam penyusunan laporan keuangan, suatu perusahaan tidak bermaksud atau berkeinginan melikuidasi atau mengurangi secara material skala usahanya.

Dalam melakukan proses audit kualitas auditor sangat diperhitungkan karena secara umum apabila reputasi Kantor Akuntan Publik baik, tingkat independen dari auditor akan lebih terpecaya. Tapi apabila reputasi KAP kurang baik dimata public, kepercayaan terhadap hasil opini audit dengan paragraph going concern pun bias saja diragukan. Reputasi Kantor Akuntan Publik (KAP) merupakan hal yang dianggap memiliki pengaruh 
terhadap opini audit going concern. KAP dengan reputasi big four diangap memiliki indepedensi dan kualutas audit lebih baik dari pada KAP dengan reputasi non big four (Piter Nainggolan: 2016).

Debt default adalah suatu keadaan ketika debitur (perusahaan) mengalami kegagalan dalam melunasi atau membayar hutang atau kewajibannya hingga bunganya pada waktu jatuh tempo. Status hutang suatu perusahaan merupakan salah satu hal yang diteliti oleh auditor dalam mengukur kondisi keuangan suatu perusahaan (Achyarsyah, 2016). Penelitian oleh Harris (2015) menemukan bahwa debt default dapat memengaruhi penerimaan opini going concern secara positif. Ini berarti bahwa perusahaan yang mendapat status debt default dapat cenderung menerima opini audit going concern. Sedangkan ukuran perusahaan merupakan ukuran atau besarnya asset yang dimiliki perusahaan. Perusahaan yang besar lebih dipercaya investor karena dipandang lebih transparan dalam mengungkapkan kinerja keuangannya. Kristiana (2012) menyatakan bahwa ukuran perusahaan tidak berpengaruh terhadap pemberian opini audit going concern. Menurut Kristiana (2012) ukuran perusahaan bukan merupakan patokan dalam pemberian opini audit going concern. Kelangsungan hidup dihubungkan dengan kemampuan manajemen dalam mengelola perusahaan.

Penelitian yang dilakukan oleh Rivan Apriyan (2014) yang berjudul "Pengaruh Kondisi Keuangan tidak berpengaruh terhadap penerimaan opini audit going concern.
Perusahaan, Debt Default dan Opini Audit Going Concern Tahun Sebelumnya terhadap Penerimaan Opini Audit Going Concern di Indonesia" menunjukkan bahwa kondisi keuangan perusahaan, debt default dan opini audit going concern tahun sebelumnya berpengaruh terhadap penerimaan opini audit going concern di Indonesia.

Penelitian yang dilakukan oleh Daulat Sahat Hatorangan Tarihozan dan Eddy Budiono (2016) yang berjudul "Pengaruh Ukuran Perusahaan, Ukuran Kantor Akuntan Publik dan Opinion Shopping terhadap Penerimaan Opini Audit Going Concern" menunjukkan hasil bahwa ukuran perusahaan, ukuran kantor akuntan publik dan opinion shopping tidak berpengaruh terhadap penerimaan opini audit going concern.

Penelitian yang dilakukan Siti Qolillah, Abdul Halim dan Reno Wulandari (2015) yang berjudul "Analisis yang mempengaruhi Opini Audit Going Concern pada Perusahaan Manufaktur yang terdaftar di Bursa Efek Indonesia" menunjukkan hasil bahwa debt default dan audit lag berpengaruh negatif terhadap opini audit going concern. Kondisi keuangan perusahaan, auditor client tenure dan ukuran perusahaan berpengaruh positif terhadap opini audit going concern. Kualitas audit tidak berpengaruh terhadap opini audit going concern.

Berdasarkan hasil penelitian ini sejalan dengan penelitian terdahulu. Hasil penelitian Qolillah dkk menunjukkan bahwa kualitas audit Hasil penelitian Apriyan yang menunjukkan bahwa debt default 
berpengaruh terhadap penerimaan opini audit going concern.

Hasil penelitian Tarihoran dan Budiono yang menunjukkan ukuran perusahaan tidak berpengaruh terhadap penerimaan opini audit going concern.

Tabel 1.1

Fenonema Pengaruh Kualitas Audit, Debt Default (Kegagalan Hutang) dan Ukuran Perusahaan terhadap Opini Audit Going Concern pada Sub Sektor Perusahaan Tekstil \& Garment periode 2014-2017

\begin{tabular}{|c|c|c|c|c|c|}
\hline $\begin{array}{c}\text { Kode } \\
\text { Saham } \\
\end{array}$ & Tahun & Kualitas Audit & $\begin{array}{c}\text { Debt Default (Kegagalan } \\
\text { Hutang) }\end{array}$ & Total Aset & $O A G C$ \\
\hline \multirow{4}{*}{ ARGO } & 2014 & $\begin{array}{l}\text { Anwar, Sugiharto \& } \\
\text { Rekan }\end{array}$ & $2,557,075,595,265.76$ & $2,105,643,751,016.14$ & $\begin{array}{l}\text { Non Going } \\
\text { Concern }\end{array}$ \\
\hline & 2015 & Anwar \& Rekan & $234,509,415,181.37$ & $1,880,704,035,632.37$ & $\begin{array}{l}\text { Non Going } \\
\text { Concern } \\
\end{array}$ \\
\hline & 2016 & Anwar \& Rekan & $2,508,057,680,983.40$ & $1,677,197,485,164.31$ & $\begin{array}{l}\text { Non Going } \\
\text { Concern }\end{array}$ \\
\hline & 2017 & Anwar \& Rekan & $2,473,396,994,365.65$ & $1,421,660,697,563.85$ & $\begin{array}{l}\text { Going } \\
\text { Concern }\end{array}$ \\
\hline \multirow{4}{*}{ ESTI } & 2014 & $\begin{array}{l}\text { Purwantono, } \\
\text { Suherman \& Surja }\end{array}$ & $668,267,516,964.72$ & $1,005,596,241,255.64$ & $\begin{array}{l}\text { Non Going } \\
\text { Concern }\end{array}$ \\
\hline & 2015 & $\begin{array}{l}\text { Purwantono, Sungkoro } \\
\text { \& Surja }\end{array}$ & $634,633,497,130.40$ & $820,673,450,930.55$ & $\begin{array}{l}\text { Going } \\
\text { Concern }\end{array}$ \\
\hline & 2016 & $\begin{array}{l}\text { Purwantono, Sungkoro } \\
\& \text { Surja }\end{array}$ & $482,085,657,323.88$ & $713,767,831,395.12$ & $\begin{array}{l}\text { Non Going } \\
\text { Concern }\end{array}$ \\
\hline & 2017 & $\begin{array}{l}\text { Purwantono, Sungkoro } \\
\& \text { Surja }\end{array}$ & $678,573,540,504.02$ & $889,435,272,294.03$ & $\begin{array}{l}\text { Non Going } \\
\text { Concern }\end{array}$ \\
\hline \multirow{4}{*}{ HDTX } & 2014 & $\begin{array}{l}\text { Drs. Bambang } \\
\text { Sudaryono \& Rekan }\end{array}$ & $52,248,199,202,396,070$ & $60,957,040,141,739,460$ & $\begin{array}{l}\text { Going } \\
\text { Concern }\end{array}$ \\
\hline & 2015 & $\begin{array}{ll}\text { Drs. } & \text { Bambang } \\
\text { Sudaryono \& Rekan }\end{array}$ & $50,442,600,648,867.97$ & $70,438,706,547,728.56$ & $\begin{array}{l}\text { Going } \\
\text { Concern }\end{array}$ \\
\hline & 2016 & Mirawati Sensi Idris & $51,640,604,238,952.91$ & $68,492,501,823,312.11$ & $\begin{array}{l}\text { Going } \\
\text { Concern }\end{array}$ \\
\hline & 2017 & Mirawati Sensi Idris & $53,616,914,418,311.49$ & $58,262,572,926,223.87$ & $\begin{array}{l}\text { Going } \\
\text { Concern }\end{array}$ \\
\hline \multirow{4}{*}{ POLY } & 2014 & $\begin{array}{l}\text { Hendrawinata Eddy } \\
\text { Siddharta \& Tanzil }\end{array}$ & $163,286,533,490,505.53$ & $3,970,379,433,002.47$ & $\begin{array}{l}\text { Going } \\
\text { Concern }\end{array}$ \\
\hline & 2015 & $\begin{array}{l}\text { Hendrawinata Eddy } \\
\text { Siddharta \& Tanzil }\end{array}$ & $16,772,192,807,928.96$ & $3,356,996,443,199.97$ & $\begin{array}{l}\text { Going } \\
\text { Concern }\end{array}$ \\
\hline & 2016 & $\begin{array}{l}\text { Hendrawinata Eddy } \\
\text { Siddharta \& Tanzil }\end{array}$ & $16,928,829,324,517.60$ & $3,337,565,605,255.65$ & $\begin{array}{l}\text { Going } \\
\text { Concern }\end{array}$ \\
\hline & 2017 & $\begin{array}{l}\text { Hendrawinata Hanny } \\
\text { Erwin \& Sumargo }\end{array}$ & $17,017,075,475,811.66$ & $3,343,593,002,901.99$ & $\begin{array}{l}\text { Non Going } \\
\text { Concern }\end{array}$ \\
\hline \multirow{2}{*}{ SSTM } & 2014 & $\begin{array}{l}\text { Doli, Bambang, } \\
\text { Sulistiyanto, Dadang \& } \\
\text { Ali }\end{array}$ & $7,456,776,356,087,472$ & $11,170,917,514,563,220$ & $\begin{array}{l}\text { Going } \\
\text { Concern }\end{array}$ \\
\hline & 2015 & $\begin{array}{l}\text { Doli, Bambang, } \\
\text { Sulistiyanto, Dadang \& } \\
\text { Ali }\end{array}$ & $6,920,820,129,599,313$ & $10,423,278,450,821,932$ & $\begin{array}{l}\text { Going } \\
\text { Concern }\end{array}$ \\
\hline
\end{tabular}




\begin{tabular}{|l|l|l|r|r|l|}
\hline \multirow{2}{*}{2016} & $\begin{array}{l}\text { Doli, Bambang, } \\
\text { Sulistiyanto, Dadang \& } \\
\text { Ali }\end{array}$ & $5,909,069,942,959,730$ & $9,688,042,555,919,308$ & $\begin{array}{l}\text { Going } \\
\text { Concern }\end{array}$ \\
\cline { 2 - 5 } 2017 & $\begin{array}{l}\text { Ishak, Saleh, } \\
\text { Soewondo \& Rekan }\end{array}$ & $5,695,172,159,021,929$ & $8,744,877,715,840,540$ & $\begin{array}{l}\text { Going } \\
\text { Concern }\end{array}$ \\
\hline
\end{tabular}

Dari Tabel I.1 dapat dilihat pada tahun 2014, Perusahaan Argo Pantes Tbk diaudit oleh KAP Anwar, Sugiharto \& Rekan dan pada tahun 2015 sampai 2017 diaudit oleh KAP Anwar \& Rekan. Pada tahun 2015 dan 2017 perusahaan mengalami penurunan hutang sebesar $90,82 \%$ dan $1.38 \%$ sedangkan pada tahun 2016 perusahaan mengalami peningkatan hutang sebesar $969.49 \%$. Pada tahun 2015 sampai dengan tahun 2017 perusahaan mengalami penurunan aset sebesar $10.68 \%, 10.82 \%$ dan $15.23 \%$. Dan pada tahun 2014 sampai 2016 perusahaan mendapatkan opini audit non going concern.

Pada tahun 2014, Perusahaan Ever Shine Tex Tbk diaudit oleh KAP Purwantono, Suherman \&Surjadan pada tahun 2015 sampai 2017 perusahaan diaudit oleh KAP Purwantono, Sungkoro \& Surja. Pada tahun 2015 dan 2016 perusahaan mengalami penurunan hutang sebesar $5.03 \%$ dan $24.03 \%$ sedangkan pada tahun 2017 perusahaan mengalami peningkatan hutang sebesar $40.75 \%$. Pada tahun 2015 dan 2016 perusahaan mengalami penurunan aset sebesar $18.38 \%$ dan $13.02 \%$ tetapi pada tahun 2017 perusahaan mengalami peningkatan aset sebesar 24.53\%. Dan pada tahun 2014, 2016 dan 2017 perusahaan mendapatkan opini audit non going concern.

Pada Tahun 2014 dan 2015, Perusahaan Panasia Indo Resources Tbk diaudit oleh KAP Drs. Bambang Sudaryono \& Rekan dan pada tahun 2016 dan 2017 perusahaan diaudit oleh KAP Mirawati Sensi Idris. Pada tahun 2015 perusahaan mengalami penurunan hutang sebesar $99.90 \%$ sedangkan pada tahun 2016 dan 2017 perusahaan mengalami peningkatan hutang sebesar $2.37 \%$ dan $3.82 \%$. Pada tahun 2015 sampai dengan 2017 perusahaan mengalami penurunan aset sebesar $99.88 \%, 2.76 \%$ dan $14.93 \%$. dan pada tahun 2014 sampai dengan tahun 2017 perusahaan mendapatkan opini audit going concern.

Pada tahun 2014 sampai dengan tahun 2016, Perusahaan Asia Pacific Fibers Tbk diaudit oleh KAP Hendrawinata Eddy Siddharta \& Tanzil dan pada tahun 2017 perusahaan diaudit oleh KAP Hendrawinata Hanny Erwin \& Sumargo. Pada tahun 2015 perusahaan mengalami penurunan hutang sebesar $89.72 \%$ sedangkan pada tahun 2016 dan 2017 perusahaan mengalami peningkatan hutang sebesar $0.93 \%$ dan 0,52\%. Pada tahun 2015 dan 2016 perusahaan mengalami penurunan aset sebesar $15.44 \%$ dan $0.57 \%$ tetapi pada tahun 2017 perusahaan mengalami penigkatan aset sebesar $0,18 \%$. Dan pada tahun 2017 perusahaan mendapatkan opini audit non going concern.

Pada tahun 2014 sampai dengan tahun 2016, Perusahaan Sunson Textile Manufacturer Tbk diaudit oleh KAP Doli, Bambang, Sulistiyanto, Dadang \& Ali dan pada tahun 2017 perusahaan diaudit oleh KAP Ishak, Saleh, Soewondo \& Rekan. Pada tahun 2015 sampai dengan tahun 2017 
perusahaan mengalami penurunan hutang sebesar $7.18 \%, 14.61 \%$, dan $3.61 \%$. Pada tahun 2015 sampai dengan 2017 perusahaan mengalami penurunan aset sebesar 6.69\%, 7.05\% dan 9.73\%. Dan pada tahun 2014 sampai dengan tahun 2017 perusahaan mendapatkan opini audit going concern.

\section{Landasan Teori}

\subsubsection{Pengertian Penerimaan Opini Audit Going Concern}

Menurut Fahmi (2015), opini audit going concern merupakan opini audit yang dikeluarkan oleh auditor untuk mengevaluasi apakah terdapat keraguan besar tentang kemampuan entitas untuk mempertahankan kelangsungan hidupnya untuk jangka waktu yang layak dan, jika berlaku, untuk mempertimbangkan kecukupan pengungkapan dalam laporan keuangan serta untuk mencantumkan paragraf penjelasan dalam laporannya yang mencerminkan kesimpulannya.

\subsubsection{Indikator Penerimaan Opini Audit Going Concern}

Indikator Penerimaan Opini Audit Going Concern diukur dengan menggunakan variabel dummy, bernilai 1 untuk opini going concern dan bernilai 0 untuk opini non going concern.

\subsubsection{Pengertian Kualitas Audit}

Menurut Eunike dan Akhmad (2015), kualitas audit adalah segala kemungkinan yang terjadi saat auditor melakukan audit atas laporan keuangan klien dapat menemukan adanya pelanggaran dalam sistem pencatatan akuntansi klien dan melaporkan dalam bentuk laporan keuangan auditan, dimana laporan tersebut harus berpedoman pada standar auditing dan kode etik akuntan publik yang berlaku

\subsubsection{Indikator Kualitas Audit}

Menurut Santoso dan Wedari (2007) dalam Syafriliani (2013) menemukan bahwa univariate bahwa auditor big 6 lebih cenderung menerbitkan opini audit going concern pada perusahaan yang mengalami financial distress dibandingkan auditor non big 6 . Menurut Syafriliani (2013), indikator dari kualitas audit adalah menggunakan variabel dummy dimana KAP termasuk dalam kategori The Big Four Auditors akan diberi kode 1 dan KAP tidak termasuk dalam kategori The Big Four Auditors akan diberi kode 0

\subsubsection{Pengertian Debt Default (Kegagalan Hutang )}

Menurut Nanda dan Siska (2015 : 46), debt default atau kegagalan pembayaran hutang atau kegagalan dalam memenuhi perjanjian hutang merupakan salah satu faktor yang dapat menimbulkan litigasi atau tuntutan pengadilan terhadap perusahaan . Menurut Januarti (2011), perusahaan gagal dalam membayar utang (debt default) maka kelangsungan usahanya menjadi diragukan, oleh sebab itu kemungkinannya auditor akan memberi opini audit going concern.

\subsubsection{Indikator Debt Default ( Kegagalan Hutang )}

Menurut Chen dan Church (1992) dalam Januarti (2011), indikator yang digunakan untuk mengukur debt default dalam penelitian ini adalah 
variabel dummy digunakan $(1=$ status debt default, 0 = tidak debt default) untuk menunjukkan apakah perusahaan dalam keadaan default atau tidak.

\subsubsection{Pengertian Perusahaan}

Ukuran

Menurut Sitanggang (2013 : 76), ukuran perusahaan dengan kapitalisasi pasar atau penjualan yang besar menunjukkan prestasi perusahaan. Perusahaan yang besar akan lebih mudah mendapatkan akses ke sumber dana untuk memperoleh tambahan modal dengan utang. Menurut Asiah (2015), semakin besar perusahaan maka auditor akan menghindari pemberian opini going concern karena perusahaan yang besar dianggap mampu mengatasi kondisi buruknya dibandingkan dengan perusahaan kecil.

\subsubsection{Indikator Ukuran Perusahaan}

Dalam Alichia (2013), indikator yang digunakan untuk mengukur ukuran perusahaan dalam penelitian ini adalah dengan menggunakan natural logaritma dari total aktiva.

kolom Collinearity Statistics pada tabel Coefficients, jika nilai VIF ada di sekitar angka 1 dan nilai Tolerance mendekati angka 1 , maka tidak terjadi multikolinieritas.

Multikolinieritas terjadi jika nilai VIF melebihi 10, dan jika nilai VIF kurang dari 10 menunjukan bahwa kolerasi antar variabel independent masih bisa ditolerir. Model regresi yang baik adalah model yang tidak terjadi multikolinieritas. Dasar pengambilan keputusan :

1. VIF $\geq 10$ : antar variabel
III. METODOLOGI PENELITIAN 3.1 Sumber Data

Peneliti melakukan penelitian pada perusahaan Tekstil dan Garment yang terdaftar di bursa efek Indonesia sebanyak 16 perusahaan periode 2014 - 2017 melalui media internet dengan situs www.idx.co.id

\subsection{Jenis Penelitian}

Jenis penelitian yang digunakan adalah penelitian deskriptif. Menurut Sugiyono (2016 : 35), penelitian deskriptif adalah penelitian yang tidak membuat perbandingan variabel itu pada sampel yang lain, dan mencari hubungan variabel itu dengan variabel lain.

\subsection{Uji Multikoliniearitas}

Menurut Ghozali (2016 : 103), uji multikolinieritas bertujuan untuk menguji apakah pada model regresi ditemukan adanya korelasi antar variabel bebas (independent). Jika terjadi korelasi maka terdapat masalah multikolinieritas. Uji multikolinieritas dilakukan dengan melihat nilai Variance Inflation Factor (VIF) tiaptiap variabel independent dan melalui

independent terjadi multikolinieritas.

2. VIF $<10:$ antar variabel independent tidak terjadi multikolinieritas.

\subsection{Model Penelitian}

1. Analisis Regresi Logistic

2. Menilai Model Fit

3. Menilai Kelayakan Model Regresi

Penelitian ini menggunakan pendekatan kuantitatif dimana penelitiaannya menghubungkan satu variabel dengan variabel lainnya dan 
biasanya bersifat angka-angka. Jenis penelitian yang digunakan adalah penelitian deskriptif dengan sifat penelitian deskriptif eksplanatory. Populasi peneltian yang akan dilakukan adalah seluruh perusahaan
Tekstil dan Garment yang terdaftar di BEI. Sampel dalam penelitian ini menggunakan metode purposive sampling dan data yang digunakan penelitian ini adalah data sekunder.

\section{Populasi Penelitian}

\begin{tabular}{|c|c|c|c|c|}
\hline No & Kode & Nama Perusahaan & Tanggal Listing & Tanggal Berdiri \\
\hline 1 & $\mathrm{ADMG}$ & Polychem Indonesia Tbk & 20 Oktober 1993 & 25 April 1986 \\
\hline 2 & ARGO & Argo Pantes Tbk & 07 Januari 1991 & 12 Juli 1977 \\
\hline 3 & BELL & Trisula Textile Industries Tbk & 03 Oktober 2017 & 11 Januari 1971 \\
\hline 4 & CNTX & Century Textile Industry Tbk & 22 Mei 1979 & 22 Mei 1970 \\
\hline 5 & ERTX & Eratex Djaya Tbk & 21 Agustus 1990 & 12 Oktober 1972 \\
\hline 6 & ESTI & Ever Shine Tex Tbk & 13 Oktober 1992 & 11 Desember 1973 \\
\hline 7 & HDTX & Panasia Indo Resources Tbk & 06 Juni 1990 & 06 April 1973 \\
\hline 8 & INDR & Indo Rama Synthetic & 03 Agustus 1990 & 03 April 1974 \\
\hline 9 & MYTX & Apac Citra Centertex Tbk & 10 Oktober 1989 & 10 Februari 1987 \\
\hline 10 & PBRX & Pan Brothers Tbk & 16 Agustus 1990 & 21 Agustus 1980 \\
\hline 11 & POLY & Asia Pasific Fibers Tbk & 12 Maret 1991 & 15 Februari 1984 \\
\hline 12 & RICY & Ricky Putra Globalindo Tbk & 22 Januari 1998 & 22 Desember 1987 \\
\hline 13 & SRIL & Sri Rejeki Isman Tbk & 17 Juni 2013 & 22 Mei 1978 \\
\hline 14 & SSTM & Sunson Textile Manufacturer Tbk & 20 Agustus 1997 & 18 November 1972 \\
\hline 15 & STAR & Star Petrochem Tbk & 13 Juli 2011 & 19 Mei 2008 \\
\hline 16 & TFCO & Tifico Fiber Indonesia Tbk & 26 Februari 1980 & 25 Oktober 1973 \\
\hline 17 & TRIS & Trisula International Tbk & 28 Juni 2012 & 13 Desember 2004 \\
\hline 18 & UNIT & Nusantara Inti Corpora Tbk & 18 April 2002 & 30 Mei 1988 \\
\hline
\end{tabular}

Sampel Penelitian

\begin{tabular}{|c|c|c|c|c|c|}
\hline \multirow{2}{*}{ No } & \multirow{2}{*}{ Kode } & \multirow{2}{*}{ Nama Perusahaan } & \multicolumn{2}{|c|}{ Kriteria } & \multirow{2}{*}{ Sampel } \\
\hline & & & 1 & 2 & \\
\hline 1 & ADMG & Polychem Indonesia Tbk & $\sqrt{ }$ & $\sqrt{ }$ & 1 \\
\hline 2 & ARGO & Argo Pantes Tbk & $\sqrt{ }$ & $\sqrt{ }$ & 2 \\
\hline 3 & BELL & Trisula Textile Industries Tbk & $\sqrt{ }$ & $x$ & \\
\hline 4 & CNTX & Century Textile Industry Tbk & $\sqrt{ }$ & $x$ & \\
\hline 5 & ERTX & Eratex Djaya Tbk & $\sqrt{ }$ & $\sqrt{ }$ & 3 \\
\hline 6 & ESTI & Ever Shine Tex Tbk & $\sqrt{ }$ & $\sqrt{ }$ & 4 \\
\hline 7 & HDTX & Panasia Indo Resources Tbk & $\sqrt{ }$ & $\sqrt{ }$ & 5 \\
\hline 8 & INDR & Indo Rama Synthetic & $\sqrt{ }$ & $\sqrt{ }$ & 6 \\
\hline 9 & MYTX & Apac Citra Centertex Tbk & $\sqrt{ }$ & $x$ & \\
\hline 10 & PBRX & Pan Brothers Tbk & $\sqrt{ }$ & $\sqrt{ }$ & 7 \\
\hline 11 & POLY & Asia Pasific Fibers Tbk & $\sqrt{ }$ & $\sqrt{ }$ & 8 \\
\hline 12 & RICY & Ricky Putra Globalindo Tbk & $\sqrt{ }$ & $\sqrt{ }$ & 9 \\
\hline 13 & SRIL & Sri Rejeki Isman Tbk & $\sqrt{ }$ & $\sqrt{ }$ & 10 \\
\hline 14 & SSTM & Sunson Textile Manufacturer Tbk & $\sqrt{ }$ & $\sqrt{ }$ & 11 \\
\hline 15 & STAR & Star Petrochem Tbk & $\sqrt{ }$ & $\sqrt{ }$ & 12 \\
\hline
\end{tabular}




\begin{tabular}{|l|l|l|c|c|c|}
\hline 16 & TFCO & Tifico Fiber Indonesia Tbk & $\sqrt{ }$ & $\sqrt{ }$ & 13 \\
\hline 17 & TRIS & Trisula International Tbk & $\sqrt{ }$ & $\sqrt{ }$ & 14 \\
\hline 18 & UNIT & Nusantara Inti Corpora Tbk & $\sqrt{ }$ & $\sqrt{ }$ & 15 \\
\hline
\end{tabular}

Dalam penelitian ini menggunakan metode analisis regresi logistic. Adapun rumus regresi logistic sebagai berikut :

$$
\begin{array}{ll}
\operatorname{Ln} \frac{\mathrm{GC} \text { Opinion }}{1-\mathrm{GC} \text { Opinion }} & =\mathrm{a}+\mathrm{b}_{1} \mathrm{KA}+\mathrm{b}_{2} \mathrm{DD}+ \\
\mathrm{b}_{3} \mathrm{UP}+\mathrm{e} & \\
\text { dimana : } & =\text { Opini Audit Going } \\
\mathrm{GC} & =\text { Konstanta } \\
\text { Concern } & \\
\mathrm{a} & =\text { Koefisien } \\
\mathrm{b}_{1}, \mathrm{~b}_{2}, \mathrm{~b}_{3} & \text { Kualitas Audit } \\
\mathrm{KA} & =\text { Debt Default } \\
\text { DD } &
\end{array}
$$

\begin{tabular}{|c|c|c|c|c|c|c|}
\hline \multirow[b]{2}{*}{ Model } & \multicolumn{2}{|c|}{$\begin{array}{c}\text { Unstandardized } \\
\text { Coefficients }\end{array}$} & \multirow{2}{*}{$\begin{array}{c}\text { Standardized } \\
\text { Coefficients } \\
\text { Beta } \\
\end{array}$} & \multirow[b]{2}{*}{$\mathrm{t}$} & \multirow[b]{2}{*}{ Sig. } & Collin \\
\hline & B & Std. Error & & & & Toler \\
\hline (Constant) & .003 & .499 & & .007 & .995 & \\
\hline KUALITAS AUDIT & .137 & .096 & .170 & -1.425 & .160 & \\
\hline DEBT DEFAULT & .670 & .144 & .518 & 4.643 & .000 & \\
\hline UKURAN PERUSAHAAN & .005 & .018 & . 031 & .265 & .792 & \\
\hline
\end{tabular}

(Kegagalan Hutang)

$$
\begin{array}{ll}
\mathrm{UP} & =\text { Ukuran Perusahaan } \\
\mathrm{e} & =\text { Tingkat Kesalah }
\end{array}
$$

\section{Hasil Dan Pembahasan \\ 4.1 Statistik Deskriptif}

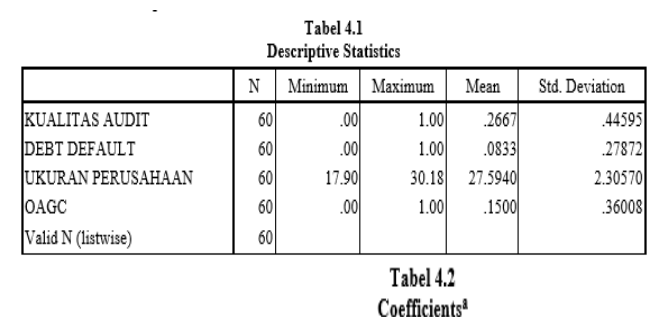

\subsection{Uji Multikolinearitas}

Uji multikolinearitas dengan nilai tolerance untuk variabel kualitas audit, debt default(kegagalan hutang) dan ukuran perusahaan masingmasing $0.844 ; 0.964 ; 0.872$ dengan nilai $\geq 0.10$ sedangkan nilai variance inflaction factors (VIF) kualitas audit, Debt default (kegagalan hutang) dan Ukuran perusahaan masing-masing $1.185 ; 1.037 ; 1.146$ dengan nilai $\leq 10$ sehingga tidak terjadi multikolinearitas.

\subsection{Menilai Model Fit}

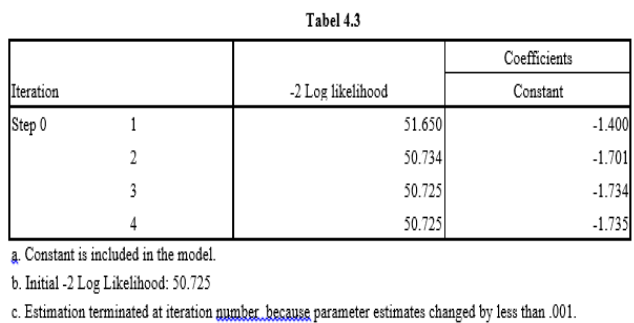

Dari tabel pertama diatas dapat dilihat bahwa nilai -2 log likehood awal (-2 LL awal) pada block number $=0$ yaitu yang hanya memasukkan konstanta saja adalah 50.725 dan pada table kedua nilai -2 log likehood akhir (-2 LL akhir) pada block number $=1$ yang memasukkan konstanta dan seluruh variabel independen adalah sebesar 34.815. Terjadi pengurangan nilai -2 Log Likehood sehingga model dikatakan fit dengan data. 


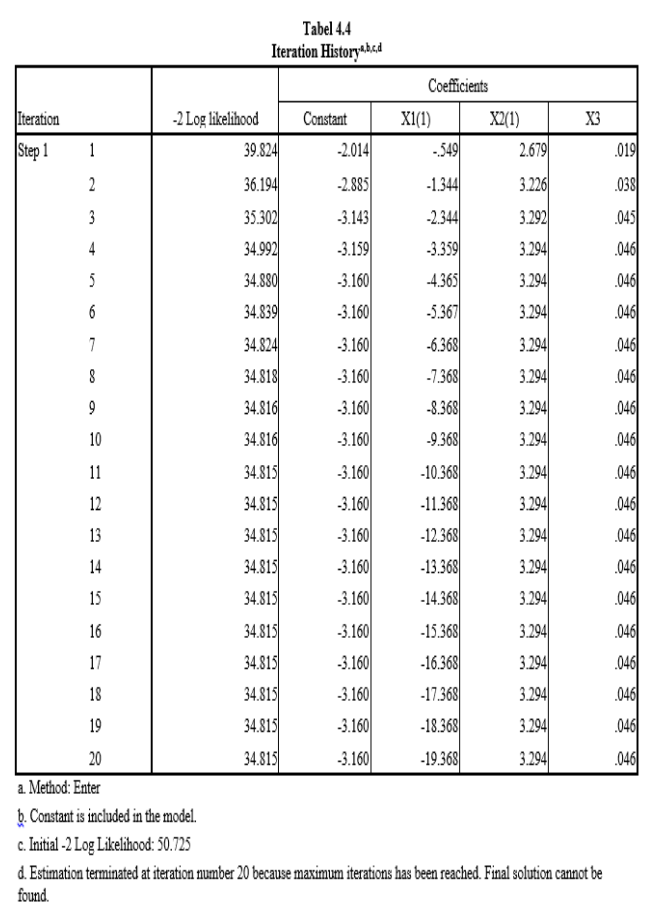

Tabel 4.5

Hosmer and Lemeshow Test

\begin{tabular}{|l|c|c|c|}
\hline Step & Chi-square & df & Sig. \\
\hline 1 & 3.961 & & 8 \\
\hline
\end{tabular}

\subsection{Kelayakan Model Regresi}

Nilai Hosmer and Lemeshow Test menunjukkan besarnya nilai signifikansi 0.861 yang nilainya diatas 0.05 sehingga dapat disimpulkan bahwa model regresi yang digunakan mampu memprediksi nilai observasinya.

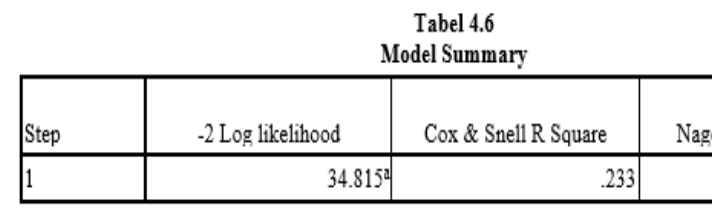

a. Estimation terminated at iteration number 20 because maximum iterations has bee solution cannot be found.

\subsection{Koefisien Determinasi}

Hasil nilai Nagelkerke $R$ Square pada penelitian ini sebesar 0.408 , yang dapat menyatakan bahwa variabilitas variabel dependen yang dapat dijelaskan oleh variabilitas variabel independen sebesar $40.8 \%$.

\subsection{Pengujian Hipotesis}

Tabel 4.7
\begin{tabular}{|ll|r|r|r|}
\hline & & Omnibus Tests of Model Coefficients \\
\hline Step 1 & Step & 15.910 & 3 & .001 \\
& Block & 15.910 & 3 & .001 \\
& Model & 15.910 & 3 & .001 \\
\hline
\end{tabular}

\subsubsection{Simultan}

\begin{tabular}{|c|c|c|c|c|c|c|c|c|c|}
\hline \multicolumn{10}{|c|}{$\begin{array}{c}\text { Tabel } 4.8 \\
\text { Variables in the Equation }\end{array}$} \\
\hline & & \multirow[b]{2}{*}{ B } & \multirow[b]{2}{*}{ S.E. } & \multirow[b]{2}{*}{ Wald } & \multirow[b]{2}{*}{$d f$} & \multirow[b]{2}{*}{ Sig. } & \multirow[b]{2}{*}{$\operatorname{Exp}(B)$} & \multicolumn{2}{|c|}{ 95\% C.Ifor $\operatorname{EXP}(B)$} \\
\hline & & & & & & & & Lower & Upper \\
\hline \multirow[t]{4}{*}{ Step $1^{2}$} & $\mathrm{X} 1(1)$ & -19.368 & 10046.861 & .000 & & .998 & .000 & .000 & \\
\hline & $\mathrm{X} 2(1)$ & 3.294 & 1.218 & 7.315 & & .007 & 26.940 & 2.476 & 293.082 \\
\hline & $\mathrm{X} 3$ & .046 & .190 & .058 & & .810 & 1.047 & .721 & 1.521 \\
\hline & Constant & -3.160 & 5.212 & .367 & & .544 & .042 & & \\
\hline
\end{tabular}

\subsubsection{Parsial}

\section{Kesimpulan Dan Saran}

Berdasarkan hasil penelitian diatas, dapat disimpulkan sebagai berikut :

1. Kualitas audit secara parsial tidak berpengaruh terhadap Penerimaan opini audit going concer, dikarenakan hasil SPSS menunjukkan nilai sig sebesar $0.998>0.05$. Hal ini berarti baik perusahaan yang diaudit oleh KAP besar maupun kecil, ketika berpotensi mengalami kebangkrutan akan memiliki peluang yang sama untuk menerima opini audit going concern.

2. Debt Default secara parsial berpengaruh terhadap Penerimaan opini audit going concer, dikarenakan, dikarenakan hasil SPSS menunjukkan nilai sig sebesar $0.007<0.05$. Hal ini berarti ketidakmampuan perusahaan dalam memenuhi kewajiban pokok 


$$
\begin{array}{lrr}
\text { dan bunga } & \multicolumn{2}{r}{\text { menyebabkan }} \\
\text { perusahaan gagal dalam } \\
\text { menjalankan usahanya dan } \\
\text { cenderung untuk menerima opini } \\
\text { audit going concern. }
\end{array}
$$

3. Ukuran perusahaan secara parsial tidak berpengaruh terhadap penerimaan opini audit going concern, dikarenakan hasil SPSS menunjukkan nilai sig sebesar $0.810>0.05$. Hal ini berarti sebuah perusahaan tergolong dalam perusahan kecil, namun jika perusahaan tersebut memiliki manajemen dan kinerja yang bagus sehingga mampu bertahan hidup dalam jangka panjang, maka semakin kecil potensi mendapatkan opini audit going concern.

4. Kualitas audit, debt default dan ukuran perusahaan secara simultan berpengaruh terhadap penerimaan opini audit going concern.

\section{REFERENSI}

Apriyan, Rivan. 2014. Pengaruh Kondisi Keuangan Perusahaan, Debt Default dan Opini Audit Going Concern Tahun Sebelumnya terhadap Penerimaan Opini Audit Going Concern di Indonesia.

Tarihoran, Daulat Sahat Hatorangan dan Eddy Budiono. 2016. Pengaruh Ukuran Perusahaan, Ukuran Kantor Akuntan Publik dan Opinion Shopping terhadap Penerimaan Opini Audit Going Concern.

Qolillah dkk. 2014. Analisis yang mempengaruhi Opini Audit Going Concern pada Perusahaan Manufaktur yang terdaftar di Bursa Efek Indonesia.

Fahmi, M.Nur. 2015. Pengaruh Audit Tenure, Opini Audit Tahun Sebelumnya dan Disclousure terhadap Opini Audit Going Concern. Akuntabilitas. Vol. VIII No.3.

Dwimilten, Eunike dan Akhmad Riduwan. 2015. Faktor-Faktor Yang Mempengaruhi Kualitas Audit. Jurnal Sekolah Tinggi Ilmi Ekonomi Indonesia (STIESIA). Surabaya

Syafriliani. 2015. Pengaruh Kualitas Audit, Likuiditas, Kondisi Keuangan Perusahaan, Ukuran Perusahaan, Pertumbuhan Perusahaan Dan Opini Audit Going Concern Sebelumnya Terhadap Pengungkapan Going Concern Pada Perusahaan Manufaktur Di Bursa Efek Indonesia Tahun 2011-2013. Jurnal Faculty Of Economics Riau University. Pekanbaru

Siska, Fini Rizki Nanda. 2015. Pengaruh Audit Tenure, Disclosure, Ukuran KAP, Debt Default, Opinion Shopping dan Kondisi Keuangan Tehadap Penerimaan Opini Audit Going Concern. Jurnal Fakultas Ekonomi Universitas Islam Riau. Vol. 24., No. 1. 
Dyah, Mirna Praptitorini dan Indira Januarti. 2011. Analisis Pengaruh Kualitas Audit, Debt Default dan Opini Shopping Terhadap Penerimaan Opini Going Concern. Jurnal Akuntansi dan Keuangan Indonesia. Volume 8- No.1.
Sitanggang, Dr. J.P. Manajemen Keuangan Perusahaan Lanjutan. Mitra Wacana Media .

Alichia, Yashinta Putri. 2013. Pengaruh Ukuran Perusahaan, Pertumbuhan Perusahaan dan Opini Audit Tahun Sebelumnya terhadap Opini Audit Going Concern. 